\title{
Corrigendum: Temporal Variability of Polycyclic Aromatic Hydrocarbons in Deep-Sea Cephalopods of the Northern Gulf of Mexico
}

\author{
Isabel C. Romero ${ }^{1 *}$, Heather Judkins ${ }^{2}$ and Michael Vecchione ${ }^{3}$ \\ ${ }^{1}$ College of Marine Science, University of South Florida, Tampa, FL, United States, ${ }^{2}$ Biological Sciences Department, \\ University of South Florida St. Petersburg, St. Petersburg, FL, United States, ${ }^{3}$ NMFS National Systematics Laboratory, \\ National Museum of Natural History, Washington, DC, United States
}

Keywords: oil spills, exposure to oil contamination, oil-residues, long-term effects, deepwater horizon spill

\section{OPEN ACCESS}

Approved by:

Frontiers Editorial Office,

Frontiers Media SA, Switzerland

${ }^{*}$ Correspondence:

Isabel C. Romero

isabelromero@mail.usf.edu

Specialty section:

This article was submitted to

Deep-Sea Environments and Ecology,

a section of the journal

Frontiers in Marine Science

Received: 31 March 2020 Accepted: 01 April 2020

Published: 05 May 2020

Citation:

Romero IC, Judkins $\mathrm{H}$ and Vecchione M (2020) Corrigendum: Temporal Variability of Polycyclic Aromatic Hydrocarbons in Deep-Sea Cephalopods of the Northern Gulf of

Mexico. Front. Mar. Sci. 7:264.

doi: 10.3389/fmars.2020.00264

\section{A Corrigendum on}

Temporal Variability of Polycyclic Aromatic Hydrocarbons in Deep-Sea Cephalopods of the Northern Gulf of Mexico

by Romero, I. C., Judkins, H., and Vecchione, M. (2020). Front. Mar. Sci. 7:54. doi: 10.3389/fmars.2020.00054

In the published article, there was an error in the institution name and city in affiliation 1. Instead of "University of South Florida St. Petersburg, St. Petersburg," it should be "University of South Florida, Tampa."

In addition, there was an error in the number source used in the Data Availability Statement. Instead of "R4.x257.000-0036" it should be "doi: 10.7266/XN8NE9DW." The corrected Data Availability Statement appears below.

\section{Data Availability Statement}

Data are publicly available through the Gulf of Mexico Research Initiative and Data Cooperative (GRIIDC) at https://data.gulfresearchinitiative.org (doi: 10.7266/XN8NE9DW).

The authors apologize for this error and state that this does not change the scientific conclusions of the article in any way. The original article has been updated.

Copyright $\odot 2020$ Romero, Judkins and Vecchione. This is an open-access article distributed under the terms of the Creative Commons Attribution License (CC BY). The use, distribution or reproduction in other forums is permitted, provided the original author(s) and the copyright owner(s) are credited and that the original publication in this journal is cited, in accordance with accepted academic practice. No use, distribution or reproduction is permitted which does not comply with these terms. 